\title{
Enhancement of power quality using UPQC for a hybrid SOFC and PMSG based wind energy system connected to weak grid
}

\author{
${ }^{1}$ G. Mallesham, ${ }^{2}$ CH. Siva Kumar \\ 1,2 Department of Electrical Engineering, UCE, Osmania University, Hyderabad \\ Email: ${ }^{1}$ gm.eed.cs@gmail.com ${ }^{2}$ ch_siva_kumar@rediffmail.com
}

\section{Received: $10^{\text {th }}$ Feb 2018, Accepted: $20^{\text {th }}$ March 2018, Published: $30^{\text {th }}$ April 2018}

\begin{abstract}
As the day-by-day the depletion of the existing conventional electrical energy resources and the incorporation of technological developments in various sectors increasing the gap between the generation and demand. These situations demands to think of the renewable energy resources or the combinations of different energy sources as hybrid energy system. This is one of the challenging tasks for the electrical engineers to effectively integrate them to grid for the required electrical demand and maintaining the quality of power. With the swift developments in power electronics systems applications to power systems for control and compensation of modern power systems made job easier for engineers to maintain the different operating conditions of the power system. In this work, modelled a hybrid renewable energy system consisting of solid oxide fuel cell and permanent magnet synchronous generator based wind energy system, weak grid and p-q theory based unified power quality conditioner. From the simulation studied it is found that the unified power quality conditioner effectively mitigated the tower shadowing effect of wind energy system, symmetrical voltage sags due to load variations and unsymmetrical swells due to unsymmetrical conditions.
\end{abstract}

Keywords: Hybrihybrid renewable energy systems, permanent magnet synchronous generator, solid oxide fuel cell, wind energy systems, weak grid.

Renewable electrical energy systems is one of the expeditious growing power sector to meet the demand on the power system during peak load periods or off-peak load period with standalone systems or the combination of different electrical power generation systems as an hybrid electrical power generation system. Out of all renewable energy systems the growth rate of the wind electrical energy [1], [2] and fuel cell systems have made a significant rate of developments. Integration, control of different characterized generating systems to a common grid is one of the challenging tasks for engineers along with the quality of power. With the advanced technological developments in the power electronics and applications to power systems has made job somewhat easier to electrical operators and engineers. But, these developments further making the engineers to face the different kinds of problems like requirements of reactive power and introducing the harmonics into the existing power system [3].

With the developments in power electronics system to power systems the various grid connected operation of wind systems have been developed [4]. Out of all the different combinations of wind generators, PMSG is the most popular in fullvariable speed wind energy conversion systems due its salient features [5]. With the introduction of the wind energy system into the weak grid experiences undamped voltage oscillations [6] is one of the main power quality issues. The power system has been subjected to different operating conditions when put into operations. As the entire power system subjected to different operating conditions like balanced and unbalanced. For these operating conditions the custom power devices is one of the best solutions. Out of all custom power devices unified power conditioner (UPQC) has all the feature to tackle the power quality issues has been aroused on the power system. The compressive review of UPQC has been presented in [7]. The work has been carryout with the main objective of maintain quality of power in an hybrid solid oxide fuel cell (SOFC) and permanent magnet synchronous generator(PMSG) based wind energy systems connected to a weak grid for different power quality issues.

The work has been organized in this paper in the following sections. In section II discussed modeling of wind turbine, permanent magnet synchronous generator, weak grid, solid oxide fuel cell, and unified power quality compensator. Implementation and simulation outcomes of the proposed hybrid weak grid system are presented in section III. Concluded the work in section IV.

\section{Simulation Models}

Wind energy is one of the freely and abundantly available energy on the globe and has become one of the major renewable energy resources. The amount of energy extracted from wind mainly depends upon the wind energy conversion system consisting of variable speed of fixed speed wind turbine, mechanical drive train, generator and the further conversion devices presented in the system that to based on the amount of energy has been converted and type of application. As the wind speed is not constant throughout the day or a particular time for consideration. For such conditions a variable wind speed turbines with double fed 
induction generator or a permanent magnet induction generator is more suitable. But, because of its better salient features than that of doubly fed induction generator a permanent magnet synchronous generator has been attractive [8]. In this work a permanent magnet synchronous generator is considered for generation of energy from wind. In the following subsections details of models used in this work has presented.

\section{A. Modelling of Wind Turbine}

A wind turbine is used to convert the kinetic energy available in the wind to the rotational mechanical energy. But, it cannot extract the complete energy available in the wind to mechanical energy [9], [10]. The amount of maximum energy that can be extracted has been estimated as:

$$
P_{m}=\frac{1}{2} \rho A v_{w}^{3} C_{p}
$$

where, $C_{P}$ - constant or power coefficient called Betz limit, $\rho$ air density $(1.225 \mathrm{~kg} / \mathrm{m} 3)$.

$$
C_{p}=f(\lambda, \beta) \cong \frac{16}{27}=0.593
$$

where, $-\lambda$ is the tip speed ratio, $-\beta$ turbine blade pitch angle. The expression for output power of variable speed wind turbine represented as

$$
P_{m}=\frac{1}{2} \rho A v_{w}^{3} C_{p}(\lambda, \beta)
$$

where, $-\rho$ is the air density $(1.225 \mathrm{~kg} / \mathrm{m} 3),-\mathrm{A}$ is the area swept by wind turbine rotor blades in $\mathrm{m}^{2},-v_{\mathrm{w}}$ is the wind velocity in $\mathrm{m} / \mathrm{s},-\mathrm{Cp}_{\mathrm{p}}$ is the power coefficient -0.59 . The mechanical output torque of the wind turbine expressed as:

$$
T_{m}=\frac{P_{m}}{\omega} \text { in N-m }
$$

where, - $\mathrm{P}_{\mathrm{m}}$ is the estimated output power of wind turbine in watts, $-\omega$ is the rotor angular velocity in $\mathrm{rad} / \mathrm{s}$. The mechanical torque of the wind turbine is further is rewritten in terms of $C_{p}$ and $V_{d}$ as [13]:

$$
T_{t}=\frac{1}{2} \rho \pi r^{3} C_{p} V_{d}^{2}
$$

The researchers [14] have discussed about the wind shear variation and the tower parameters and tower shadow effected disturbed wind speed[13].The expression for tower shadowing disturbance is represented as:

$$
V_{d}=V_{h}\left(1+v_{m}+v_{\text {tower }}\right)
$$

where, $-\mathrm{T}_{\mathrm{t}}$ is mechanical torque of the wind turbine, - $V_{h}$ is the incoming wind speed, - $\rho$ is air density, $\mathrm{V}_{\mathrm{d}}$ is disturbed wind speed, - $\mathrm{V}_{\mathrm{m}}$ is wind shear variation, $-v_{\text {tower }}$ is tower shadow disturbance. Wind turbine systems with the following technical specifications are used for the simulation: Nominal wind turbine mechanical output power 21.6e6, Base wind speed $-14 \mathrm{~m} / \mathrm{s}$, Maximum power at base wind speed (p.u of nominal mechanical power) 1, pitch angle controller gain $\mathrm{K}_{\mathrm{p}} 5, \mathrm{~K}_{\mathrm{i}} 25$, Maximum pitch angle -45 .

B. Modelling of permanent magnet synchronous generator

As the wind energy conversion system need to have an electrical generator to convert mechanical rotational energy to electrical energy. Many researchers have been working on the electrical generators for different applications. Out of the existing generators PMSG has been extensively using for wide variety of applications [13], [14]. The dynamic model of the direct-driven generator in synchronous rotating frame has been build up for this work. The permanent magnet effect is considered in the equations, and its flux is represented by [15].

$$
\begin{aligned}
& V_{s d}=R_{s} i_{s d}+L_{d} \frac{d i_{s d}}{d t}-L_{q} \omega i_{s q} \\
& V_{s q}=R_{s} i_{s q}+L_{q} \frac{d i_{s q}}{d t}+L_{d} \omega i_{s d}+\omega \lambda
\end{aligned}
$$

where, $\mathrm{L}_{\mathrm{q}}$ and $\mathrm{L}_{\mathrm{d}}$ are generator quadrature and direct axis inductances, $R_{s}$ is the resistance, $\omega$ generator speed. The equation for electromagnetic torque is represented by:

$$
T_{e}=\frac{3}{2} p\left[\left(L_{d}-L_{q}\right) i_{s q} i_{s d}-\lambda_{m} i_{s q}\right]
$$

For synchronous machines with cylindrical rotor, $L_{d} \cong L_{q}$. Hence above equation is reduced as

$$
T_{e}=\frac{3}{2} p\left[\lambda_{m} i_{s q}\right]
$$

where, $\mathrm{p}$ - number of pole pairs, $\lambda_{m}$ - permanent magnet flux in webers, $i_{s d}$ - $\mathrm{d}$ - axis stator current in Ampere A, $i_{s q}-\mathrm{q}$-axis stator current in Ampere A, $V_{s d}$ - d- axis stator voltage in volts $\mathrm{V}, V_{s q}$ - q-axis stator voltage in volts $\mathrm{V}, \omega-$ generator rotational speed in $\mathrm{rad} / \mathrm{s}$.

\section{Weak Grid}

The ratio between short circuit power and rated wind form power defines as a weak grid. The value of short circuit power in BB6 is $S S C \approx 120 \mathrm{MVA}$ this ratio has been calculated as[16]:

$$
\tau=\frac{S_{S C}}{P_{W F}} \approx 5.5
$$

values of $r \leq 20$ are considered as a weak grid connection.

\section{Modelling of Solid Oxide Fuel}

The technological developments and features of fuel cells has been introducing into the existing power system as an independent or as a cogenerating system [17]. For this propose work modeled a dynamic model of SOFC with an appropriate control systems [18]. The chemical 
reactions at anode, cathode and the total chemical reactions of SOFC are for the considered SOFC are shown below:

cathode equation :

$$
\mathrm{O}_{2}+4 \bar{e} \rightarrow 2 \mathrm{O}^{2-}
$$

Anode equations:

$$
\mathrm{H}_{2}+\mathrm{O}^{2-} \rightarrow \mathrm{H}_{2} \mathrm{O}+2 \bar{e}
$$

or

$$
\mathrm{CO}+\mathrm{O}^{2-} \rightarrow \mathrm{CO}_{2}+2 \bar{e}
$$

Overall equation:

$$
\mathrm{H}_{2}+\mathrm{O}_{2}+\mathrm{CO} \rightarrow \mathrm{H}_{2} \mathrm{O}+\mathrm{CO}_{2}
$$

The stack output voltage V is represented by[16]:

$$
V=N_{\mathrm{o}}\left(E_{0}+\frac{R T}{2 F}\left[\frac{\ln p H_{2} p_{o 2}^{0.5}}{p H_{2} O}\right]\right)
$$

where, E - the voltage associated with the reaction free energy in $\mathrm{V}, \mathrm{R}$ - gas constant in $[\mathrm{J} /(\mathrm{kmol} \mathrm{K})]$ and, $\mathrm{r}$ - ohmic losses of the stack in $\Omega$ . The SOFC output is connected to the grid through a universal bride converter and a three phase transformer of rating $100 \mathrm{MVA}, 690 \mathrm{~V} / 33 \mathrm{kV}$. The following are details of SOFC: $\mathrm{V}_{\mathrm{dc}}$ rated fuel cell terminal voltage-690 V, T- the operating temperature- $1273 \mathrm{k}, \mathrm{E}_{\mathrm{o}}$ the ideal standard potential$1.18 \mathrm{~V}, \mathrm{~N}_{\mathrm{o}}$ - number of series connected cells in SOFC stack - 723, $K_{\tau}$ modeling constant $0.993 \times 10 \mathrm{e}^{3} ; \mu_{s}$ fuel utilization factor setting - 0.8, $\mathrm{K}_{\mathrm{H} 2}$ hydrogen valve molar constant $0.843 \mathrm{~mol} /$ (s.atm), $\mathrm{KH}_{2 \mathrm{O}}$ - water valve molar constant - $0.281 \mathrm{~mol} /(\mathrm{s} . \mathrm{atm}), \mathrm{K}_{\mathrm{O} 2}$ oxygen valve molar constant- $2.25 \mathrm{~mol} /(\mathrm{s} . \mathrm{atm}), \quad \tau \mathrm{H}_{2}$ hydrogen flow response time - $26.1 \mathrm{sec}, \tau \mathrm{H}_{2} \mathrm{O}$ water flow response time - $78.3 \mathrm{sec}, \tau \mathrm{O}_{2}$ oxygen flow response time$2.91 \mathrm{sec}, \mathrm{r}$ ohmic losses $-0.126 \mathrm{ohms}$.

\section{E. Modelling of Unified Power Quality} Compensator

Day-by-day a wide variety of applications with different operating characteristics has been connecting to the power systems leads to increasing the complexity of power system operation. This is one of the challenging tasks for the electrical engineers to maintain the quality of power when operating in different operating conditions. To tackle different operating conditions and maintain effectively the power quality different custom power devices has been using.
Out of all the existing devices UPQC is one which can effectively maintain more power quality issues on the power system [19]. At PCC the shunt compensator injecting the currents in to the power system to compensates the change in active power $\Delta \mathrm{P}$ and reactive power $\Delta \mathrm{Q}$ fluctuations. The series controller compensates the fluctuations of voltages of the system by injecting the voltage by subtracting the PCC voltage from the reference voltage [20].

$$
\begin{aligned}
& P_{\text {shunt } C}(t)=\frac{3}{2} V_{d}^{P C C}(t) \cdot I_{d}^{\text {shuC }}(t) \\
& Q_{\text {shunt } C}(t)=\frac{3}{2} V_{d}^{P C C}(t) \cdot I_{q}^{\text {shuC }}(t)
\end{aligned}
$$

Eq. 18 and Eq.19 further, re-written by ignoring the voltage variations at $\mathrm{PCC}$ as:

$$
\begin{aligned}
& P_{\text {shunt } C}(t)=k_{p}^{\prime} \cdot I_{d_{\text {shc } C}}(t) \\
& Q_{\text {shunt } C}(t)=k_{q}^{\prime} \cdot I_{q_{\text {shc }}}(t)
\end{aligned}
$$

For a voltage source based inverter a linear relationship between the generated power and the controller voltages to obtain the current in Eq. 20 and in Eq. 21 are

$$
\begin{aligned}
& P_{\text {shunt } C}(t)=k_{p}^{\prime} \cdot E_{d_{s h c C}^{*}}^{*}(t) \\
& Q_{\text {shunt } C}(t)=k_{q}^{\prime} \cdot E_{q_{\text {shc } C}^{*}}^{*}(t)
\end{aligned}
$$

\section{Implementation and simulation results}

Fig. 1 shows the network used for implementing the proposed work to enhance the quality of power of a hybrid distribution system connected to a weak grid [21]. In Fig. 2, BB (i) represents the bus bar number. $\mathrm{Zij}$ represents the impedance between the bus bars $i$ and $j$. BB1 represents the grid; ZTR is the impedance of the transmission line. UPQC connected at bus bar BB6.

Wind turbine system connected to the BB7 through a transmission line. SW is the switch to connect and to disconnect the load to the system considered. The wind system having total capacity of of $21.6 \mathrm{MW}$ is connected to the weak grid through a transformer rating of $690 \mathrm{~V} / 33 \mathrm{kV}, 630 \mathrm{kVA}$. A fixed capacitor bank of $200 \mathrm{kVAr}$ connected at wind energy system. The $100 \mathrm{~kW}$ rated proton exchange membrane fuel cell system connected through a transformer of rating 100 MVA $690 / 33 \mathrm{kV}$ to the distribution weak grid. 


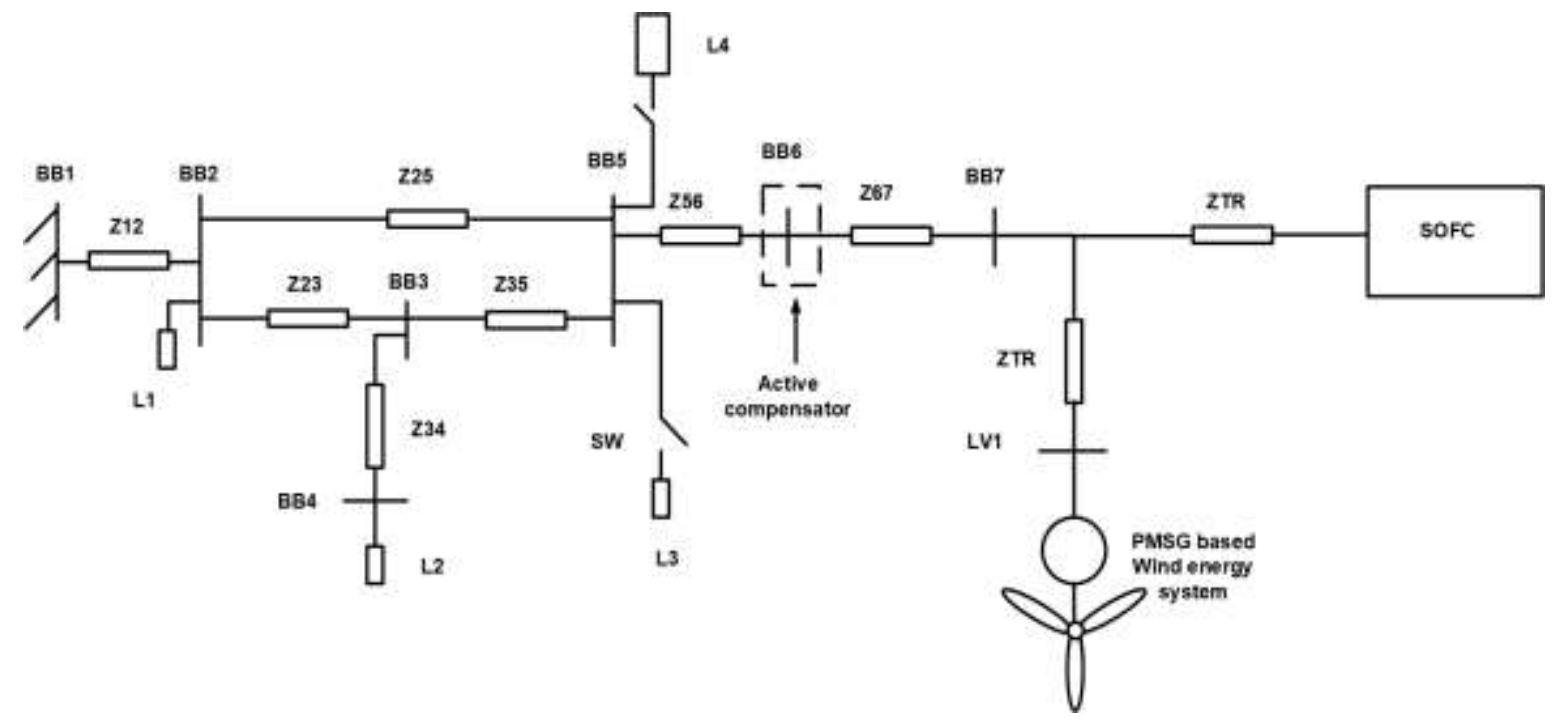

Fig. 1. Overall schematic diagram hybrid PMSG based wind and solid oxide fuel cell systems connected to weak grid.

The following case studies carried in this work to improve the quality of power of hybrid weak grid system using UPQC and without using UPQC.

- Case 1: Balanced sags(With and Without UPQC)

- $\quad$ Case 2: Unbalanced swells (With UPQC)

\section{A. Case 1: Balanced Sags(With and Without}

$U P Q C)$

In this case study the following steps has been carried out during the simulation. (a) simulation started at time $\mathrm{t}=0.0$ seconds along with the shadowing effect and series controller of the UPQC. at time $\mathrm{t}=2.5$ seconds the UPQC controllers is put into operation.(b) at time $t=3.5$ seconds a inductive load of $15 \mathrm{MW}+\mathrm{j}$ 6.31 MVAr is connected and retained till the end of the simulation period of 6 seconds.(c) at time $\mathrm{t}=4$ seconds a inductive load of $12 \mathrm{MW}-\mathrm{j} 2.4 \mathrm{MVAr}$ is connected and retained till the end of the simulation period of 6 seconds.(d) at time $\mathrm{t}=4.5$ seconds a capacitive load of $\quad 9.2$ $\mathrm{MW}+\mathrm{j} 1.85 \mathrm{MVAr}$ is connected and retained till the end of the simulation period of 6 seconds.(e) at time $\mathrm{t}=5$ seconds a inductive load of $20 \mathrm{MW}+\mathrm{j} 15$ MVAr is connected and retained till the end of the simulation period of 6 seconds. During the entire simulation period the wind speed has been varied continuously form $13 \mathrm{~m} / \mathrm{s}$ to $15 \mathrm{~m} / \mathrm{s}$ with an average value of $14 \mathrm{~m} / \mathrm{s}$.

Fig. 2 clearly demonstrates power fluctuations due to tower shadowing effect of wind turbine has been generated for variations in wind speeds as per in eq. 6 and torque equation eq. 5. The oscillations in active power and reactive at grid are $-2.6 \mathrm{MW}$ to -1.6 MW and 2.2 MVAr to 8.2 MVAr respectively. Similar fluctuations observed at PMSG based wind system and SOFC. If these oscillations continually exits which effects the entire system. The UPQC shunt controller is put into operation at $\mathrm{t}=2.5$ seconds. The simulation results

Fig. 2. Active and reactive powers(with and without UPQC) (a) $P$ at grid (b) Q at grid (c) P at PMSG based wind system (d) Q at PMSG based wind system (e) P at SOFC system and (f) Q at SOFC system.

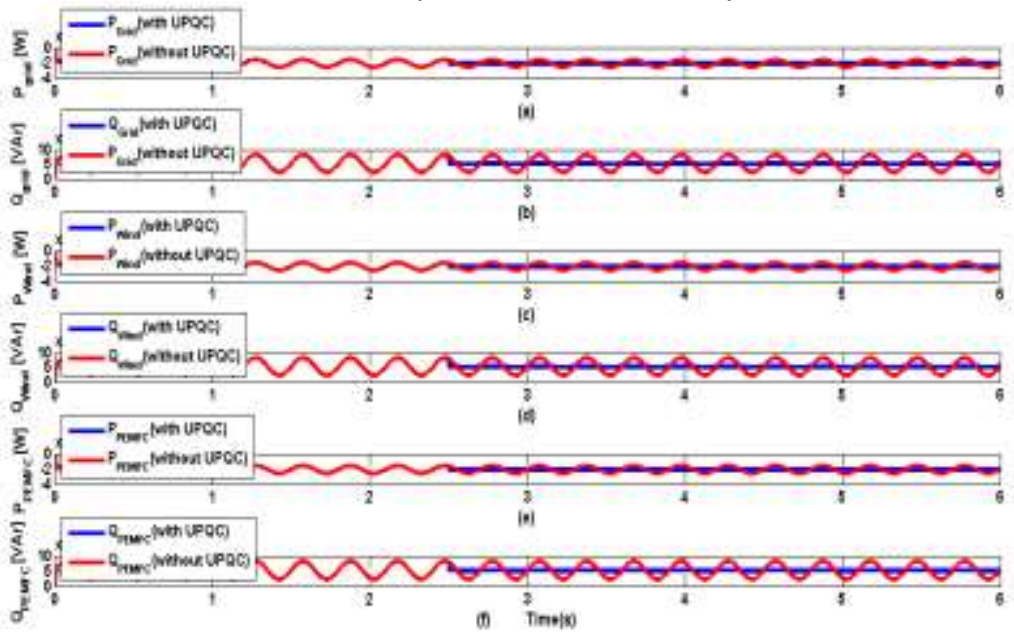


Fig. 3. Voltages across (a) Phase Voltage at common coupling (b)Phase voltage at grid (c) Phase voltage at Wind energy system (d)Phase voltages at SOFC.

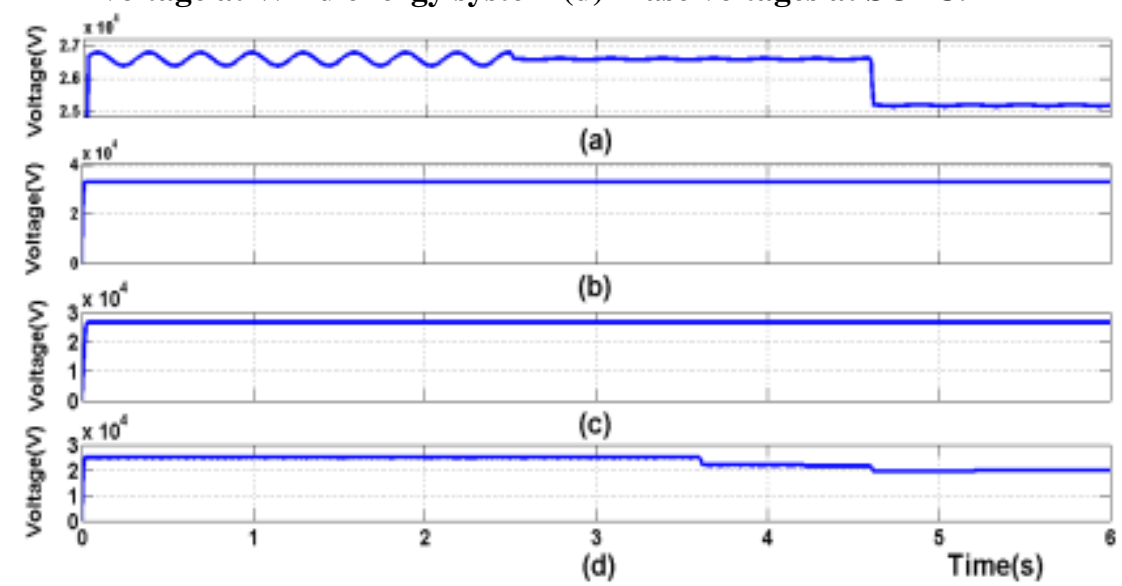

demonstrated the mitigation of oscillations in a weak grid at the PMSG based wind system and SOFC. From the results of the simulation studies of Fig. 3(a) demonstrates the variations in terminal voltages at point of common coupling between $2.64 \times 10^{4}$ Volts(peak-peak) and $2.68 \times 10^{4}$ Volts(peak-peak) which is crossing the limits of IEC standard
IEC61000-4-15. Hence, under these circumstances a controller can effectively bring back to constant. It is further demonstrated the voltages at grid, PMSG based wind system and SOFC in 3(b), 3(c) and 3(d) respectively. It is further observed that the voltages at the grid and the PMSG based wind systems has been maintained constant by the controller effectively.

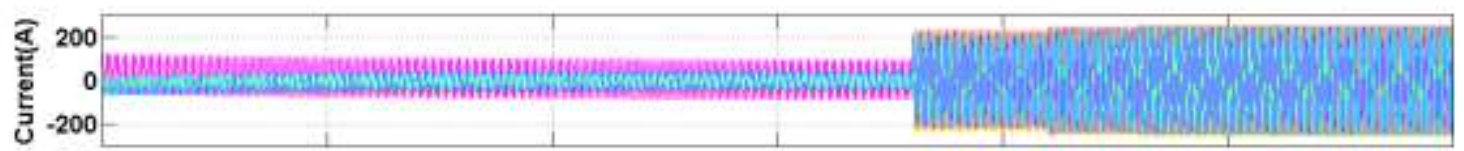

(a)

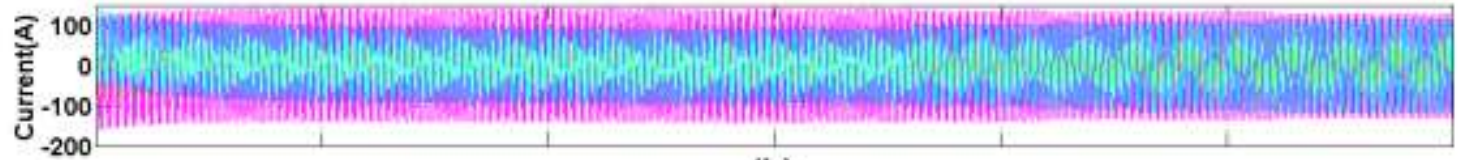

(b)

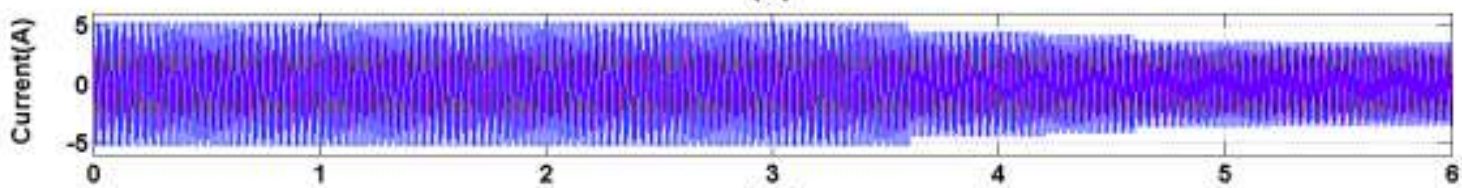

(c)

Fig. 4. Three phase currents with (UPQC) at (a) Grid (c) Wind energy system (c) SOFC.

Fig. 4 and 5 demonstrates the simulation results of currents drawn from grid, PMSG based wind energy system and SOFC by the application of UPQC and without UPQC respectively

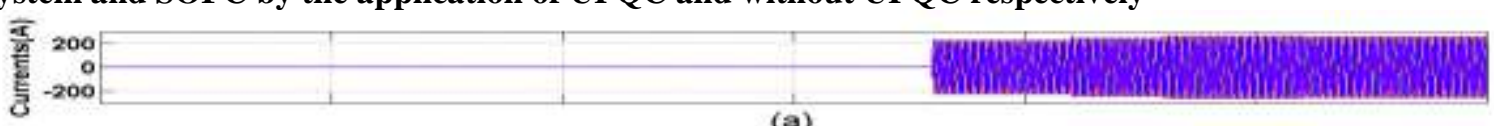

(a)

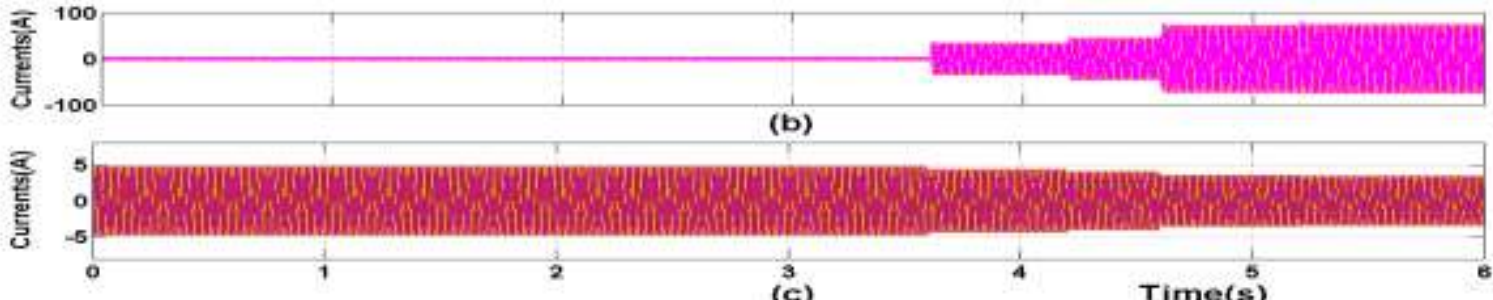

(c)

Time(s)

Fig. 5. Three phase currents without (UPQC) at (a) grid (b) DFIG based wind energy system (c) PEMFC system. 

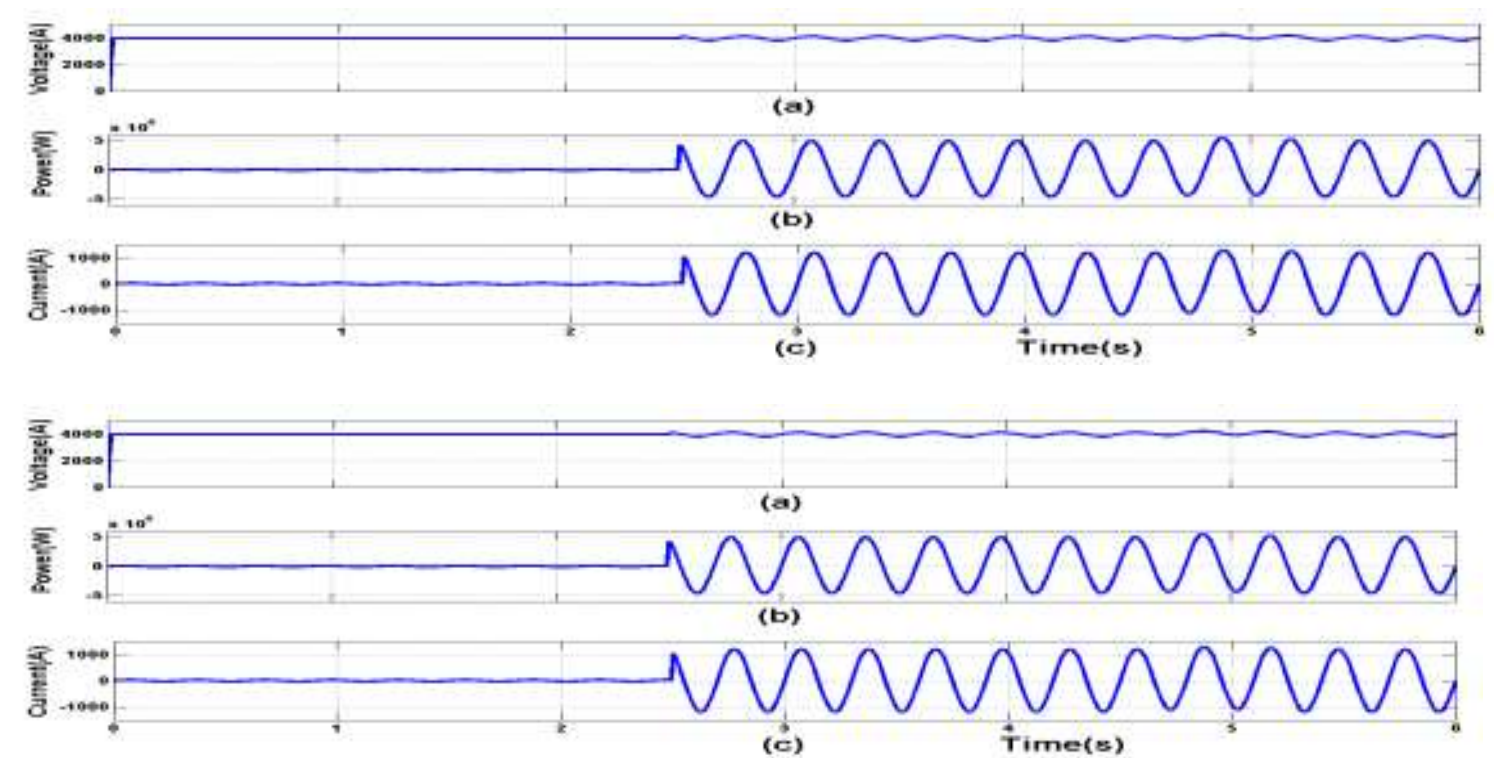

Fig. 6. (a) Voltage across the capacitor of the UPQC (b) DC side power of the UPQC (c) DC current.

In Fig. 6(a), 6(b) and 6(c) represented simulation results of the variations in DC voltage, DC powers and DC currents and at DC side of the UPQC for variations in active power on the system considered. As the shunt active filter of the UPQC put into operation at $\mathrm{t}=2.5$ seconds. To maintain the DC link voltage the shunt active filer draws the currents form the point of common connection. Out of the available sources on the existing power system the $\mathrm{SOFC}$ is the weakest of the three.

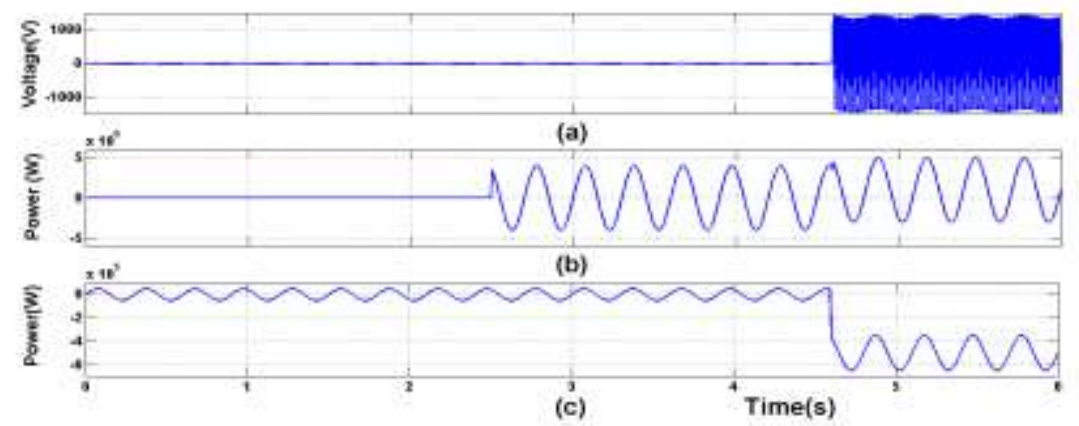

Fig. 7. (a) Series injected voltage of UPQC phase a (b) Shunt controller active power variations (c) Series controller active power variations

The simulation results shown in Fig. 7(a), Fig.7(b) and Fig.7(c) represents the UPQC series controller phase a voltage, UPQC shunt controller active power variations and UPQC series controller power variations respectively. The moment the complete UPQC is put into operation, the variations of the reactive power on the system is provided by the shunt controller alone i.e., no reactive power burden is on the sources of the power system considered during the sag conditions is shown in Fig. 7(b). To compensate the voltage at PCC the UPQC series controller injects the voltages. Fig. 7(a) that has been shows the series controller injected phase a voltage to maintain the terminal voltages.

In Fig. 7(a), Fig. 7(b) and Fig. 7(c) shows the simulation results of the variations in DC voltage, DC powers and DC currents and at DC side of the UPQC for variations in active power on the system considered. As the shunt active filter of the UPQC put into operation at $t=2.5$ seconds. To maintain the DC link voltage the shunt active filter draws the currents form the point of common connection.

The simulation results shown in Fig. 8(a), Fig. 8(b) and Fig. 8(c) represents the UPQC series controller phase 'a' voltage, UPQC shunt controller active power variations and UPQC series controller power variations respectively. The moment the complete UPQC is put into operation, the variations of the reactive power on the system is provided by the shunt controller alone i.e., no reactive power burden is on the sources of the power system considered during the sag conditions is shown in Fig. 8(b). To compensate the voltage at PCC the UPQC series controller injects the voltages. Fig. 8(a) that has been shows the series controller injected 
phase a voltage to maintain the terminal voltages within the IEEE 1159-1995[23].

Case 2: B. Unbalanced Swells (With UPQC)

The simulation has been carried out in the following sequence of operations:

- Simulation work has been started at time $\mathrm{t}$ $=0.0$ seconds along with the shadowing effect and series. Controller of the UPQC. At time $t=2.5$ seconds the shunt part of upqc controllers is put into operation.

- at time $\mathrm{t}=3.5$ seconds a a load of $15 \mathrm{MW}$ $+\mathrm{j}$ 6.31MVAr is connected.

- at time $\mathrm{t}=4 \mathrm{a}$ load of $12 \mathrm{MW}-\mathrm{j} 2.4 \mathrm{MVAr}$ is connected. at time $t=4.5-4.7$ seconds a three phase fault with fault resistance of $0.001 \mathrm{ohms}$ and a ground resistance of 0.001 ohms has been created on low voltage side of the $630 \mathrm{kVA}, 33 \mathrm{kV} / 690 \mathrm{~V}$ which is connected in between the $\mathrm{Z} 25$ and $\mathrm{Z} 35$ distributed line parameters.

- at time $t=5-5.2$ seconds a line to line fault with the resistance of 9 ohms(high resistance fault) with ground resistance of 0.001 ohms has been created on low voltage side of the $630 \mathrm{kVA}, 33 \mathrm{kV} / 690 \mathrm{~V}$ which is connected in between the Z25 and Z35 distributed line parameters.

- at time $t=5.5-5.7$ seconds a line to ground fault with ground resistance of $0.001 \mathrm{ohms}$ has been created on low voltage side of the $630 \mathrm{kVA}, 33 \mathrm{kV} / 690 \mathrm{~V}$ which is connected in between the $\mathrm{Z} 25$ and $\mathrm{Z} 35$ distributed line parameters.

The effect of wind turbine is nullified by the conditioner which is similar to the previous case study. From Fig. III-B(a) it is clearly shown that during this period of time on $\mathrm{HV}$ side of the transformer balanced voltage profile has been maintained constant by the UPQC controller action. At time $\mathrm{t}=4.5-4.7$ seconds a three phase fault with ground resistance of $0.001 \mathrm{ohms}$. During this period of time the voltage has raised from $80 \mathrm{~V}_{\text {(peak-peak) }}$ to $160 \mathrm{~V}_{\text {(peak-peak) }}$ is created at low voltage side of the transformer is shown in Fig. III-B(b).

At time $t=4.5-4.7$ seconds a three phase fault with ground resistance of $0.001 \mathrm{ohms}$. During this period the voltage has raised from $115 \mathrm{~V}$ (peak-peak) to $225 \mathrm{~V}$ (peak-peak) is created at low voltage side of the transformer is shown in Fig. 9(b). Similarly, a line to line fault with fault resistance with fault resistance of 9 ohms with ground resistance of 0.001 ohms created during $\mathrm{t}=5.2-5.4$ seconds and a line to ground fault with a ground resistance of $0.001 \mathrm{ohms}$ created. The simulated results shown in Fig. 9(c) and Fig. 9(d) are respectively to created the voltage swells.

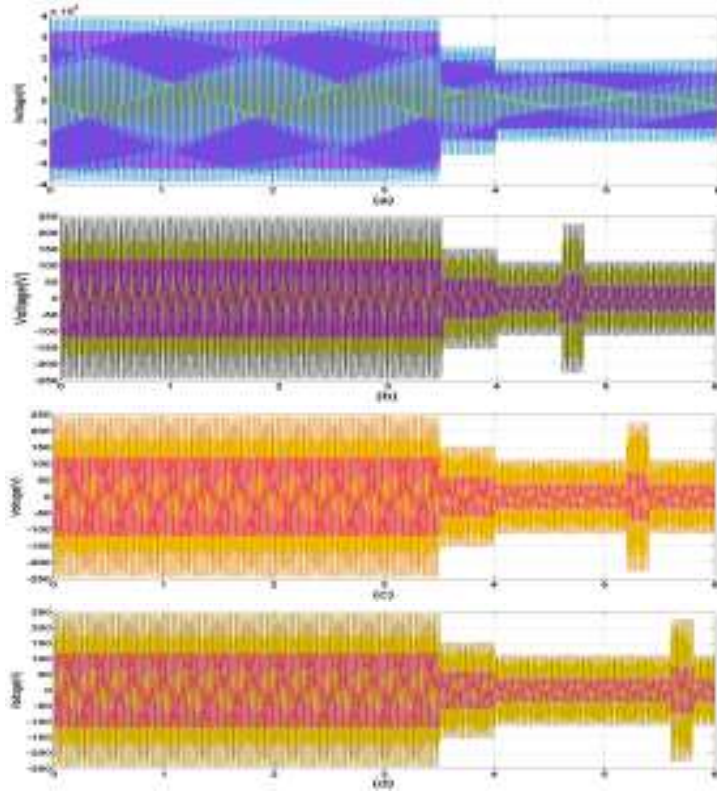

Fig. 8. Three phase voltages (a) At $33 \mathrm{kV}$ side of the transformer for three phase fault. (b) Voltages at low voltage side of the transformer for three phase fault with ground resistance of 0.001 ohms. (c) Voltages at low voltage side of the transformer for line-to-line fault with fault resistance of $9 \mathrm{ohms}$ and with ground resistance of $0.001 \mathrm{ohms}$. (d) Voltages at low voltage side of transformer for line to ground fault with ground resistance of $0.001 \mathrm{ohms}$.

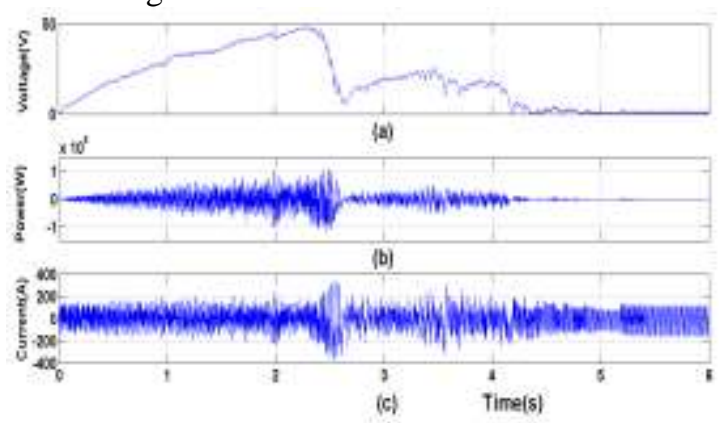

Fig. 9. (a) Series injected voltage of UPQC phase a (b) Shunt controller active power variations (c) Series controller active power variations

\section{Conclusion}

In this work, modeled a p-q theory based UPQC to improve the power quality of an hybrid renewable system with solid oxide fuel cell and permanent magnet synchronous generator based wind energy systems connected to a weak rid. The simulation results shown that the developed system effectively eliminated active power and reactive power oscillations due to the tower shadowing effect of the wind system within the international standards of IEC 61000-4-15. Further it mitigated the symmetrical voltage sags due to load variations and unsymmetrical swells due to unsymmetrical conditions within the IEEE 1159-1995. 


\section{References}

[1] V. Yaramasu, B. Wu, P. C. Sen, S. Kouro, and M. Narimani, "Highpower

wind energy conversion systems: State-of-the-art and emerging technologies," Proceedings of the IEEE, vol. 103, no. 5, pp. 740-788, May 2015.

[2] G. W. E. Council, "Global wind report 2015annual market update," Global Wind Energy Council, Brussels, Belgium.[Online]. Available httpllwwwgwec.

netlwpcontent/uploads/vip/GWEC-Global-Wind20, 2016.

[3] S. R"onnberg and M. Bollen, "Power quality issues in the electric power system of the future," The Electricity Journal, vol. 29, no. 10, pp. 49-61, 2016.

[4] F. Blaabjerg and K. Ma, "Future on power electronics for wind turbine systems," IEEE Journal of Emerging and Selected Topics in Power Electronics, vol. 1, no. 3, pp. 139-152, Sept 2013.

[5] M. Rahimi, "Modeling, control and stability analysis of grid connected pmsg based wind turbine assisted with diode rectifier and boost converter," International Journal of Electrical Power \& Energy Systems, vol. 93, pp. 84 96, 2017.

[6] L. Fan and Z. Miao, "An explanation of oscillations due to wind power plants weak grid interconnection," IEEE Transactions on Sustainable Energy, 2017.

[7] V. Khadkikar, "Enhancing electric power quality using upqc: A comprehensive overview," IEEE transactions on Power Electronics, vol. 27, no. 5, pp. 2284-2297, 2012.

[8] J. C. Hui, A. Bakhshai, and P. K. Jain, "An energy management scheme with power limit capability and an adaptive maximum power point tracking for small standalone pmsg wind energy systems," IEEE Transactions on Power Electronics, vol. 31, no. 7, pp. 4861-4875, 2016.

[9] M. Ragheb and A. M. Ragheb, "Wind turbines theory-the betz equation and optimal rotor tip speed ratio," in Fundamental and advanced topics in wind power. InTech, 2011.

[10] I. Standard, “61400-2-(2006) design requirements for small wind turbines," International Electrotechnical Commission, 2006.

[11] H. Battista and R. Mantz, "Wind turbine control systems principles, modeling and gain scheduling design," 2007.
[12] H. Sintra, V. Mendes, and R. Mel'icio, "Modeling and simulation of wind shear and tower shadow on wind turbines," Procedia Technology, vol. 17, pp. 471-477, 2014.

[13] N. A. Orlando, M. Liserre, R. A. Mastromauro, and A. Dell'Aquila, "A survey of control issues in pmsg-based small wind-turbine systems," IEEE transactions on Industrial Informatics, vol. 9, no. 3, pp. 1211-1221, 2013.

[14] V. Yaramasu, A. Dekka, M. J. Durn, S. Kouro, and $\mathrm{B}$. $\mathrm{Wu}$, "Pmsgbased wind energy conversion systems: survey on power converters and controls," IET Electric Power Applications, vol. 11, no. 6, pp. 956-968, 2017.

[15] F. Khater and A. Omar, "A review of direct driven pmsg for wind energy systems," Journal of Energy and Power Engineering, vol. 7, no. 8, 2013. [16] L.-J. Cai and I. Erlich, "Doubly fed induction generator controller design for the stable operation in weak grids," IEEE Transactions on Sustainable Energy, vol. 6, no. 3, pp. 1078-1084, 2015.

[17] L. Barelli, G. Bidini, and A. Ottaviano, "Integration of sofc/gt hybrid systems in microgrids," Energy, vol. 118, pp. 716-728, 2017.

[18] Y. Zhu and K. Tomsovic, "Development of models for analyzing the load-following performance of microturbines and fuel cells," Electric Power Systems Research, vol. 62, no. 1, pp. 1-11, 2002.

[19] V. Khadkikar, "Enhancing electric power quality using upqc: A comprehensive overview," IEEE Transactions on Power Electronics, vol. 27, no. 5, pp. 2284-2297, May 2012.

[20] M. Farias, P. Battaiotto, and M. Cendoya, "Wind farm to weak-grid connection using upqc custom power device," in Industrial Technology (ICIT), 2010 IEEE International Conference on. IEEE, 2010, pp. 1745-1750.

[21] Z. Saad-Saoud, M. Lisboa, J. Ekanayake, N. Jenkins, and G. Strbac, "Application of statcoms to wind farms," IEE Proceedings-Generation, Transmission and Distribution, vol. 145, no. 5, pp. 511-516, 1998. 